\title{
Role of DHA, ARA, \& phospholipids in brain development: An Indian perspective
}

\author{
Pankaj Garga , Ranjan Kumar Pejaver ${ }^{\mathrm{b}}$, Manpreet Sukhija ${ }^{\mathrm{c}, *}$, Anjali Ahuja ${ }^{\mathrm{d}}$ \\ a Department of Neonatology, Institute of Child Health, Sir Ganga Ram Hospital, Rajinder Nagar, New Delhi -110060, India \\ ${ }^{\mathrm{b}}$ Meenakshi Hospitals, \#90, 50 Feet Road, Banashankari 1st Stage, Hanumantha Nagar, Bangalore, India \\ ${ }^{\mathrm{c}}$ Medico-marketing, Nestle Nutrition, Nestlé House, Jacaranda Marg, DLF Phase 2, Gurgaon 122002, India \\ ' Head Medico-Marketing E' Public Health, Nestle Nutrition, Nestlé House, Jacaranda Marg, DLF Phase 2, Gurgaon 122002, India
}

\section{A R T I C L E I N F O}

\section{Article history:}

Received 11 May 2017

Received in revised form 15 September 2017

Accepted 22 September 2017

Available online 23 September 2017

\section{Keywords:}

DHA

ARA

Infant brain development

Cognitive development

\section{A B S T R A C T}

Long-chain polyunsaturated fatty acids such as docosahexaenoic acid and arachidonic acid play vital roles in brain development during infancy. In India, LCPUFA intake during pregnancy is substantially low, mostly attributed to poor dietary intake. Infants are likely to have similar trend considering low intake of DHA in lactating mothers as well as low/absent DHA in bovine milk and standard infant formulae. Studies on maternal intake of DHA during pregnancy and lactation are in favor of routing supplementation. Though studies on benefits of DHA and ARA supplemented infant formulas have shown heterogeneous results, the latest long term studies showing better cognitive skills.

(C) 2017 Published by Elsevier, a division of RELX India, Pvt. Ltd on behalf of INDIACLEN.

\section{Introduction}

The nutritional requirements of infants during the first year of life are exceptionally high, in view of the rapid growth and development that occurs during this phase. ${ }^{1}$ Particularly, brain development is fastest in the early years of life compared to the rest of the body, making it most vulnerable to nutritional deficiencies. $^{2,3}$ The neonatal brain, which is one-third to one-fourth of the size of the adult brain at birth, grows rapidly to reach $72 \%$ of adult volume within the first year, suggesting that the majority of brain growth happens during the first year of life. ${ }^{4}$ The brain volume achieved at the end of the first year determines later intelligence. Poor growth during early life may not be compensated by growth in brain volume that occurs after infancy. ${ }^{5}$ Brain development in infants follows a genetic program that is majorly influenced by several factors, including nutrition. Recently, the effect of essential fatty acids (EFA), especially long-chain polyunsaturated fatty acids (LCPUFA), on brain development has received considerable attention. Docosahexaenoic acid (DHA) and arachidonic acid (ARA), which are important members of the omega-3 (n-3) and omega-6 (n-6) fatty acid families respectively, are found in the gray matter of the brain; ${ }^{3}$ DHA and ARA are important components of neuronal membranes, which constitute $20 \%$ of the brain's dry

\footnotetext{
* Corresponding author.

E-mail address: manpreet.sukhija@IN.nestle.com (M. Sukhija).
}

weight. ${ }^{6}$ Phospholipids (PL) are also vital nutrients that play an important role in brain development. ${ }^{7-11}$ Phospholipids have been demonstrated to be effective carriers of essential PUFAs, mainly DHA, to the brain. ${ }^{8,9}$

In this review, we discuss some of the current evidence on the benefits of DHA, ARA, and phospholipids in brain development during the early years of life, their levels in human milk and infant formulas, and the relevance of the DHA:ARA ratio in infant formulas.

\section{Role of LCPUFAs and phospholipids in brain development}

\subsection{DHA and ARA}

Docosahexaenoic acid (22:6[n-3]) forms the main structural component of nerve cells and is present in large quantities in the brains of mammals. ${ }^{12,13}$ The function of DHA in the brain is to help in the transmission of messages through nerve cells and to protect the brain against loss of scaffolding proteins and oxidative degradation of lipids, thus helping maintain the plasticity of the brain. DHA also plays an important role in gene expression, myelination, and growth and differentiation of neurons. ${ }^{14} \mathrm{DHA}$ is also a vital membrane component of the photoreceptor cells of the eye, and proper functioning of the photoreceptor cells is essential for vision. ${ }^{13}$

Arachidonic acid is an omega-6 (n-6) fatty acid that plays an important role in brain functioning, including in neuronal firing, 
signal transmission, and long-term potentiation. In addition, ARA preserves hippocampal neuron membrane plasticity, protects the brain against oxidative stress, and aids in the synthesis of new protein in brain tissues. ${ }^{1}$

\subsubsection{Sources of DHA and ARA}

Docosahexaenoic acid is available for consumption as DHA itself or in the form of its precursors $\alpha$-linolenic acid (ALA,18:3[n-3]) and eicosapentaenoic acid (EPA, 20:5[n-3]), which is present in large amounts in fish, sea foods, and to some extent in poultry and eggs. However, vegetable fats and oils do not contain DHA or EPA. ${ }^{12}$ Fish oil is the most commonly used source of n-3 fatty acids, and microalgal oil is an excellent alternative to fish oil. The microalgal oil is produced from several microalgae species, including Schizochytrium sp., Crypthecodinium cohnii, etc. ${ }^{15}$ Alpha-linolenic acid is available from soybean and canola oil, flax seed oil, and some nuts. Arachidonic acid is found in the flesh of lean red meat and chicken; egg yolk; and human milk. ${ }^{12}$

\subsubsection{Biosynthesis and metabolism}

The metabolic pathway is common for both n-3 and n- 6 fatty acids, resulting in potential competition between the families of fatty acid for enzyme activity. Linoleic acid and ALA are converted into ARA and EPA respectively by a series of desaturation and elongation reactions (Fig. 1). The EPA-to-DHA conversion involves elongation of EPA to 24:6(n-3) occurring sequentially, followed by a single $\beta$-oxidation process, to yield DHA. ${ }^{12,16-18}$ The desaturation enzymes delta-5 desaturase (D5D) and delta-6 desaturase (D6D) catalyze the rate-limiting steps in the conversion of PUFAs and are recognized as main determinants of PUFA levels. ${ }^{19}$ The activity of desaturase enzymes is influenced by genetics, nutritional status, hormones, and feedback inhibition by the end products. ${ }^{20}$ The D5D and D6D enzymes are coded by the genes FADS1 and FADS2, respectively. ${ }^{19}$ Polymorphisms in FADS1 and FADS2 genes have been demonstrated to influence the levels of DHA in maternal red blood cell phospholipids and may affect the child's DHA supply during pregnancy. ${ }^{21}$ Furthermore, if the dietary intake of ALA is high and LA consumption low, there is an increase in EPA and DHA levels, due to the reduced competition for the D6D enzyme. ${ }^{22}$ However, most human diets are richer in LA than ALA, which results in increased conversion of these precursors to n- 6 fatty acids. $^{20}$ Studies suggest that the conversion rate of ALA to DHA is very low and ranges from $<1 \%$ to $10 \%$, with higher conversion rates seen in women compared to men. ${ }^{23,24}$ In vegetarians, ALA supplementation has been demonstrated to increase the proportion of EPA, but not DHA. ${ }^{25}$ Furthermore, the conversion rates are particularly low in infants (especially in preterm infants), with evidence suggesting that the precursors are not sufficiently converted to DHA to promote optimal brain development. ${ }^{26,27}$ On the other hand, dietary DHA has been demonstrated to be readily absorbed and incorporated into the lipids of plasma and blood cells. ${ }^{12}$

\begin{tabular}{|c|c|c|}
\hline Omega -6 & & Omega -3 \\
\hline $\begin{array}{l}\text { Linoleic acid- } \\
\text { LA } ;(18: 2 \text { n-6) }\end{array}$ & & $\begin{array}{l}\text { Alpha Linoleic acid- } \\
\alpha-\mathbf{L A} ;(18: 3 \mathrm{n}-3)\end{array}$ \\
\hline$\downarrow$ & Delta6-desaturase & $\downarrow$ \\
\hline $\begin{array}{l}\text { Gamma Linoleic acid - } \\
\qquad(18: 3 n-6)\end{array}$ & & $(18: 4 n-3)$ \\
\hline$\downarrow$ & Elongase & $\downarrow$ \\
\hline $\begin{array}{l}\text { Dihomogamma Linolenic acid- } \\
\qquad(20: 3 n-6)\end{array}$ & & $\begin{array}{l}\text { Eicosapentaenoic acid- } \\
\text { EPA;(20:5 n-3) }\end{array}$ \\
\hline$\downarrow$ & Delta5-desaturase & $\downarrow$ \\
\hline $\begin{array}{l}\text { Arachidonic acid- } \\
\qquad \mathbf{A A} ;(20: 4 \text { n-6) }\end{array}$ & & $(22: 5 n-3)$ \\
\hline$\downarrow$ & Elongase elongase & $\downarrow$ \\
\hline $\begin{array}{l}\text { Docosatraenoic acid- } \\
\qquad(22: 4 n-6)\end{array}$ & & $(24: 5 n-3)$ \\
\hline$\downarrow$ & Delta6-desaturase & $\downarrow$ \\
\hline$(24: 4 n-6)$ & & $(24: 6 n-3)$ \\
\hline$\downarrow$ & Beta-oxidation & $\downarrow$ \\
\hline $\begin{array}{c}(24: 5 n-6) \\
\quad \downarrow\end{array}$ & & $\begin{array}{l}\text { Docosahexaenoic acid- } \\
\text { DHA; }(22: 6 n-3)\end{array}$ \\
\hline $\begin{array}{l}\text { Docosapentaenoic acid- } \\
\text { DPA;(22:5 n-6) }\end{array}$ & & \\
\hline
\end{tabular}

Source: Heaton AE, et al. Frontiers in Human Neuroscience. 2013:7(774).

Fig. 1. Common metabolic pathway for the synthesis of DHA and ARA. ${ }^{18}$ 


\subsubsection{Maternal-to-fetal transfer of DHA}

It is well known that nutrient transfer through the placenta can affect fetal metabolism, growth, and development. The transfer of fatty acids to the fetus is influenced by the amount of maternal fatty acid intake, as well as by various physiological processes that occur during pregnancy, including placental function. ${ }^{28}$ Observational studies have suggested that increased DHA intake during pregnancy results in higher maternal-to-fetal transfer of DHA. ${ }^{12}$

\subsubsection{DHA and ARA accumulation in the fetal brain}

Docosahexaenoic acid is rapidly accumulated in the brain from week 30 of pregnancy to 2 years postpartum (Fig. 2). ${ }^{1,29}$ Approximately $67 \mathrm{mg}$ of DHA is accrued by the fetus per day, thereby increasing its brain weight and making it important for the mother to have adequate DHA intake during this time. The DHA accretion during lactation is $70-80 \mathrm{mg} /$ day, and this huge demand for DHA during lactation depletes maternal stores and may take months to correct even partially. ${ }^{13}$ On the whole, the concentration of DHA increases nearly 30-fold during the growth spurts of the brain, which corresponds to the beginning of the third trimester of pregnancy to 18 months after birth. ${ }^{30}$ During these growth spurts, the brain is extremely vulnerable to nutritional deficiencies. ${ }^{3}$ Preterm infants largely miss out on DHA accretion during the last trimester and thus would benefit from external supplementation. $^{31}$

Arachidonic acid begins accumulating in the brain during the last trimester of pregnancy and continues to accumulate until 2 years of postnatal age (Fig. 2). ${ }^{1}$ About $95 \mathrm{mg} /$ day of ARA is accrued during the last 5 weeks of gestation; this is nearly twice the amount of DHA accrued during the same period. Most of the ARA is accumulated in the adipose tissue and skeletal muscles, with relatively lesser amounts accumulated in the brain. ${ }^{32}$

\subsubsection{Levels of DHA and ARA in human milk}

Worldwide, variable levels of DHA and ARA have been reported in breast milk. This has been attributed largely to differences in the dietary intake of sources of these fatty acids. ${ }^{33}$ Table 1 shows mean DHA and ARA levels in human milk. . $^{33,34}$

DHA levels in vegans have been reported to be $0.05 \%$ of total fatty acids. Populations with high fish intake report the highest milk DHA content. ${ }^{35}$ The mean concentration of DHA in breast milk in Chinese women has been reported to vary from $0.44 \%$ of total fatty acids in pastoral regions to as high as $2.8 \%$ in marine regions. ${ }^{36}$ The DHA concentration in the breast milk of native American women has been reported to be $0.097 \%$ of total fatty acids. ${ }^{37}$

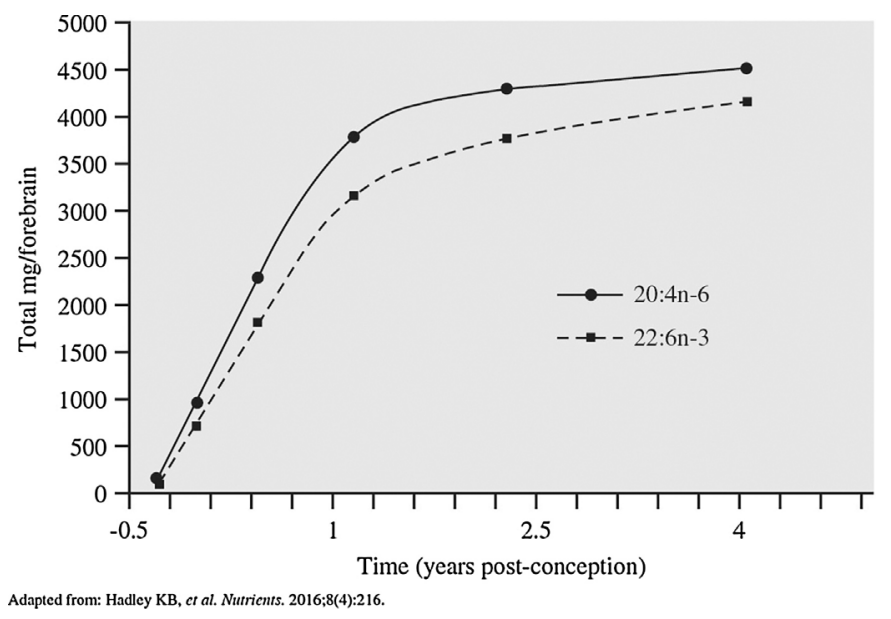

Fig. 2. Accumulation of DHA and ARA in the foetal brain. ${ }^{1}$
Table 1

Mean DHA and ARA levels in human milk. ${ }^{33,34}$

\begin{tabular}{lll}
\hline & Mean levels $(\mathrm{mg} / 100 \mathrm{kcal})$ & Mean levels $(\%$ of total fatty acids) \\
\hline DHA & $9.8-12.5$ & $0.32 \% \pm 0.22 \%$ \\
ARA & $16.7-23.6$ & $0.47 \% \pm 0.13 \%$ \\
\hline
\end{tabular}

DHA: Docosahexaenoic acid; ARA: Arachidonic acid.

The levels of ARA in human milk are much more stable than DHA, which is highly important, as it provides preformed ARA at a time when brain growth and development are most critical. The majority of ARA in human milk is from maternal stores of ARA, rather than from dietary LA. ${ }^{1}$ Studies suggest that the average intake of ARA and DHA in exclusively breastfed infants is approximately $169 \mathrm{mg} /$ day and $115 \mathrm{mg}$ /day, respectively. At the age of 12 months, with an average milk intake of $600-900 \mathrm{~mL} /$ day, the ARA intake is $118-178 \mathrm{mg} / \mathrm{day}{ }^{38,39}$

\subsubsection{Maternal LCPUFA intake supplementation and infant outcomes}

It is clear that DHA and ARA form an important component of brain structure and function and can thus potentially influence neurodevelopmental outcomes. Available evidence suggests that due to dietary variations, the mean DHA and ARA intake in pregnant women can be substantially lower than the recommended intake. ${ }^{26}$ Several studies have demonstrated that maternal DHA supplementation during pregnancy and/or during lactation increases the fetus's/infant's DHA status. ${ }^{40-49}$ In a double-blinded study involving 590 pregnant women, maternal supplementation with cod liver oil until three months after delivery was associated with increased DHA levels in maternal and infant plasma and umbilical tissues. ${ }^{42}$ In another study, increasing breast milk DHA levels through maternal supplementation for the first 12 weeks postpartum caused a dose-dependent increase in the infant plasma and erythrocyte phospholipid DHA levels. ${ }^{41}$ Hence, it is important to ensure that the fetal essential fatty acid requirements are adequately met with a proper diet and supplementation.

It is also well known that DHA is an important structural component of retinal photoreceptors and cortical gray matter. In a randomized, placebo-controlled trial, DHA supplementation during pregnancy was associated with a significant difference in mean visual acuity scores between the DHA group and the placebo group ( $3.8 \pm 1.1$ cycles/degree vs. $3.2 \pm 0.7$ cycles/degree) at 4 months, suggesting the vital role of DHA in the maturation of the visual system. ${ }^{44} \mathrm{~A}$ recent trial assessed the long-term effects of high prenatal DHA exposure during gestation on visual evoked potentials (VEPs) in school-age children. The study confirmed the findings of an earlier study in the same population that reported an association between cord DHA and better visual acuity. $^{45,46}$

Maternal DHA supplementation has demonstrated beneficial effects on several indicators of early cognitive function, including better mental and psychomotor development at 11 months of age, ${ }^{46}$ enhanced attention functioning during second year of life, ${ }^{47}$ better performance at problem-solving tasks at 9 months of age, ${ }^{48}$ and better mental processing scores at 4 years of age. ${ }^{49}$

\subsubsection{Effects of DHA/ARA supplementation in infants and its outcomes}

The beneficial effects of LCPUFA supplementation in on brain development in infants were demonstrated in early studies that compared infants who were breastfed with LCPUFAs to infants fed formulas without LCPUFAs. ${ }^{50-52}$ From thereon, several intervention trials studied the benefits of LCPUFA supplementation during infancy on various aspects of child development. Table 2 shows a summary of trials reporting DHA/ARA-related outcomes in 
Table 2

Summary of trials reporting DHA/ARA-related outcomes in children. ${ }^{53-67}$

\begin{tabular}{|c|c|c|c|c|c|}
\hline Reference & $\mathrm{N}$ & Participants & Duration & Intervention & Key findings \\
\hline \multicolumn{6}{|c|}{ Short-term studies } \\
\hline Birch et al. ${ }^{53}$ & -56 & $\begin{array}{l}\text { Term infants } \\
\text { assessed at } 4 \\
\text { months and } 12 \\
\text { months of age }\end{array}$ & $\begin{array}{l}\text { From } 0-4 \text { days until } 17 \\
\text { weeks of age }\end{array}$ & $\begin{array}{l}\text { - Formula with } 0.35 \% \text { or } 0.36 \% \text { DHA } \\
\text { and } 0.72 \% \text { ARA } \\
\text { - Control }\end{array}$ & $\begin{array}{l}\text { Mean increase of } 7 \text { points on MDI of BSID-II } \\
\text { in supplemented group }\end{array}$ \\
\hline $\begin{array}{l}\text { Pastor } \\
\text { et } \text { al. }^{54}\end{array}$ & -1342 & Term infants & & $\begin{array}{l}\text { - Formula with } 0.32 \% \text { DHA and } 0.64 \% \\
\text { ARA } \\
\text { - Control }\end{array}$ & $\begin{array}{l}\text { Lower incidence of bronchiolitis/bronchitis } \\
\text { during the first year of life in the } \\
\text { supplemented group }\end{array}$ \\
\hline $\begin{array}{l}\text { Birch et } \text { al. }^{55} \\
\quad \text { (DIAMOND }\end{array}$ & $\begin{array}{c}-343 \\
\text { study) }\end{array}$ & Term infants & $\begin{array}{l}\text { From } 1-9 \text { days } \\
\text { until } 12 \text { months }\end{array}$ & $\begin{array}{l}\text { - Formula with } 0.64 \% \text { ARA and } 0.32 \% \text { or } \\
\text { 0.64\% or } 0.96 \% \text { DHA } \\
\text { - Control: } 0 \% \text { DHA }\end{array}$ & $\begin{array}{l}\text { Significantly poorer VEP visual acuity at } 12 \\
\text { months of age in infants fed control formula } \\
\text { compared to DHA-supplemented formula }\end{array}$ \\
\hline $\begin{array}{l}\text { Drover } \\
\text { et al. }{ }^{56}\end{array}$ & -181 & $\begin{array}{l}\text { Term infants } \\
\text { followed up to the } \\
\text { age of } 18 \text { months }\end{array}$ & $\begin{array}{l}\text { From } 1-9 \text { days to } 12 \\
\text { months }\end{array}$ & $\begin{array}{l}\text { - Control (0\% DHA) } \\
\text { - } 0.32 \% \text { DHA } \\
\text { - } 0.64 \% \text { DHA } \\
\text { - } 0.96 \% \text { DHA }\end{array}$ & $\begin{array}{l}\text { Higher Mental Development Index scores in } \\
\text { DHA-supplemented children compared to } \\
\text { controls }\end{array}$ \\
\hline $\begin{array}{l}\text { Meldrum } \\
\text { et al. }\end{array}$ & -420 & $\begin{array}{l}\text { Term infants } \\
\text { followed up to the } \\
\text { age of } 18 \text { months }\end{array}$ & From birth to 6 months & $\begin{array}{l}\text { - Fish oil containing DHA }(250 \mathrm{mg} / \mathrm{d})+ \\
\text { EPA }(60 \mathrm{mg} / \mathrm{d}) \\
\text { - Placebo }\end{array}$ & $\begin{array}{l}\text { Significantly higher percentile ranks of } \\
\text { - later developing gestures at } 12 \text { and } 18 \\
\text { months } \\
\text { - total number of gestures }\end{array}$ \\
\hline $\begin{array}{l}\text { D’Vaz } \\
\quad \text { et al. }\end{array}$ & -420 & $\begin{array}{l}\text { Term infants with a } \\
\text { high atopic risk } \\
\text { followed up at } 6 \\
\text { and } 12 \text { months }\end{array}$ & From birth to 6 months & $\begin{array}{l}\text { - Fish oil containing DHA }(280 \mathrm{mg})+ \\
\text { EPA }(110 \mathrm{mg}) \\
\text { - Control oil }\end{array}$ & $\begin{array}{l}\text { Fish oil supplementation was associated } \\
\text { with: } \\
\text { Lowered allergen-specific Th2 responses } \\
\text { Elevated polyclonal Th1 responses }\end{array}$ \\
\hline $\begin{array}{l}\text { Lapillonne } \\
\text { et al. }\end{array}$ & -325 & Term infants & Up to 12 months & $\begin{array}{l}\text { - Infant and follow on formula con- } \\
\text { taining } 17 \mathrm{mg} \text { of } \mathrm{DHA} / 100 \mathrm{kcal} \text { and } \\
34 \mathrm{mg} \text { of ARA } / 100 \mathrm{kcal} \\
\text { - Control }\end{array}$ & $\begin{array}{l}\text { Lower incidence of bronchitis/bronchiolitis, } \\
\text { nasal congestion, cough, and diarrhea in the } \\
\text { supplemented group }\end{array}$ \\
\hline $\begin{array}{l}\text { Foiles } \\
\text { et al. }{ }^{60}\end{array}$ & -91 & Term infants & Up to 12 months & $\begin{array}{l}\text { - Three formulas containing } 0.64 \% \text { ARA } \\
\text { and either } 0.32 \%, 0.64 \% \text {, or } 0.96 \% \text { DHA } \\
\text { - Control }\end{array}$ & $\begin{array}{l}\text { Supplemented group was associated with: } \\
\text { - Lower risk of allergic illnesses in the first } \\
\text { year } \\
\text { - Delayed time to first allergic illness and } \\
\text { skin allergic illness } \\
\text { Trend towards reduced wheeze/asthma }\end{array}$ \\
\hline \multicolumn{6}{|c|}{ Long-term studies } \\
\hline $\begin{array}{l}\text { Colombo } \\
\text { et al. } \\
\text { (DIAMOND }\end{array}$ & $\begin{array}{l}\text { - } \text { LCPUFA }=62 \\
\text { - Placebo }=19 \\
\text { study follow-up) }\end{array}$ & $\begin{array}{l}\text { Term infants ( } 18 \\
\text { mo) followed up to } \\
\text { the age of } 6 \text { years }\end{array}$ & From birth to 12 months & $\begin{array}{l}\text { - DHA }(0.32 \%, 0.64 \% \text {, and } 0.96 \% \text { of total } \\
\text { fatty acids) + ARA }(0.64 \%) \\
\text { - Placebo }\end{array}$ & $\begin{array}{l}\text { Significant positive effects on: } \\
\text { - Rule learning and inhibition tasks from } 3 \\
\text { to } 5 \text { years } \\
\text { - Peabody Picture Vocabulary Test at } 5 \\
\text { years } \\
\text { - Weschler Primary Preschool Scales of } \\
\text { Intelligence at } 6 \text { years }\end{array}$ \\
\hline $\begin{array}{l}\text { Willatts } \\
\text { et al. }{ }^{62}\end{array}$ & $\begin{array}{l}- \text { LCPUFA }=71 \\
\text { - Control } \\
\quad \text { group }=76 \\
- \text { Breastfed } \\
\text { group }=88\end{array}$ & $\begin{array}{l}\text { Term infants } \\
\text { followed up to the } \\
\text { age of } 6 \text { years }\end{array}$ & From birth to 4 months & $\begin{array}{l}\text { - Formula with DHA + ARA } \\
\text { - Formula with no DHA/ARA } \\
\text { - Reference breastfed group }\end{array}$ & $\begin{array}{l}\text { Faster information processing scores in } \\
\text { children who received LCPUFAs }\end{array}$ \\
\hline \multicolumn{6}{|c|}{ Systematic review and meta-analysis } \\
\hline $\begin{array}{l}\text { Qawasmi } \\
\text { et al. }{ }^{63}\end{array}$ & $\begin{array}{l}12 \text { RCTs; } \\
\mathrm{N}=1802\end{array}$ & $\begin{array}{l}\text { Term and preterm } \\
\text { infants }\end{array}$ & $\begin{array}{l}\text { Starting within } 1 \text { month of } \\
\text { birth }\end{array}$ & $\begin{array}{l}\text { - Formulas with LCPUFAs } \\
\text { - Unsupplemented formula }\end{array}$ & $\begin{array}{l}\text { No significant benefit on early cognition } \\
\text { with LCPUFA supplementation }\end{array}$ \\
\hline $\begin{array}{l}\text { Simmer } \\
\text { et al. }\end{array}$ & $\begin{array}{l}15 \text { RCTs; } \\
\mathrm{N}=1889\end{array}$ & Term infants & - & $\begin{array}{l}\text { - Formulas with LCPUFAs } \\
\text { - Unsupplemented formula }\end{array}$ & $\begin{array}{l}\text { - No beneficial effects on neurodevelop- } \\
\text { mental outcomes } \\
\text { - Benefits in visual acuity not consistent }\end{array}$ \\
\hline $\begin{array}{l}\text { Qawasmi } \\
\text { et al. }^{65}\end{array}$ & $\begin{array}{l}16 \text { RCTs; } \\
\mathrm{N}=1949\end{array}$ & $\begin{array}{l}\text { Term and preterm } \\
\text { infants }\end{array}$ & $\begin{array}{l}\text { Starting within } 1 \text { month of } \\
\text { birth }\end{array}$ & $\begin{array}{l}\text { - Formulas with LCPUFAs } \\
\text { - Unsupplemented formula }\end{array}$ & $\begin{array}{l}\text { Significant benefit with LCPUFA } \\
\text { supplementation on infants' visual acuity at } \\
2,4 \text {, and } 12 \text { months of age }\end{array}$ \\
\hline $\begin{array}{l}\text { Koletzko } \\
\text { et al. }{ }^{66}\end{array}$ & $\begin{array}{l}20 \text { systematic } \\
\text { reviews/meta- } \\
\text { analyses, } 78 \\
\text { RCTs in Asian } \\
\text { population }\end{array}$ & $\begin{array}{l}\text { Pregnant and } \\
\text { lactating women, } \\
\text { term infants, } \\
\text { preterm infants }\end{array}$ & - & LCPUFA supplementation & $\begin{array}{l}\text { - For term infants, supplementation with } \\
\text { higher doses (DHA } \geq 0.32 \% \text { and ARA } \\
\geq 0.66 \% \text { ) and longer duration (up to } 1 \text { year } \\
\text { of age) trended towards likely benefit } \\
\text { - Scarcity of data on LCPUFA supplemen- } \\
\text { tation in Asian population }\end{array}$ \\
\hline $\begin{array}{l}\text { Jasani } \\
\text { et al. }{ }^{67}\end{array}$ & 15 RCTs $\mathrm{N}=1889$ & Term infants & - & $\begin{array}{l}\text { - Formulas with LCPUFAs } \\
\text { - Unsupplemented formula }\end{array}$ & $\begin{array}{l}\text { No beneficial effects with LCPUFA } \\
\text { supplementation on neurodevelopmental } \\
\text { outcomes or visual acuity }\end{array}$ \\
\hline
\end{tabular}

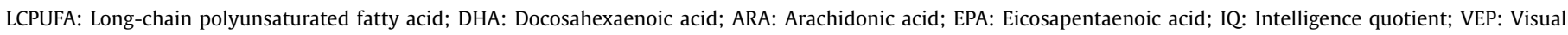
evoked potential; MDI: Mental Development Index BSID-II: Bayley Scales of Infant Development, 2nd edition. 
children. ${ }^{53-67}$ We used PUBMED to identify key trials on LCPUFA supplementation in infants. Several individual trials have demonstrated significantly improved neurodevelopmental outcomes with DHA supplementation. However, results from systematic review and meta-analyses do not favor LCPUFA supplementation for cognitive benefits in infants. ${ }^{63,64,67}$ One of the probable reasons for the contradicting results is the use of Bayley Scales of Infant Development (BSID) as an outcome measure in these metaanalyses. The BSID is a composite score of infants' attainment of normal developmental milestones and does not always provide a detailed outcome of specific cognitive mechanisms. There is an ongoing debate on whether BSID should be used for evaluating cognitive outcomes with LCPUFA supplementation, since the effects of LCPUFA are not evident in BSID compared to other measures. Furthermore, BSID may not be appropriate in evaluating long-term cognitive outcomes. ${ }^{61}$

As mentioned earlier, preterm infants need DHA supplementation, since DHA accretion is interrupted in preterm infants and there is inadequate conversion from precursors in preterm infants. Studies suggest that DHA levels are higher in the milk of mothers who deliver prematurely compared to those who deliver at term. ${ }^{68}$ Research in preterm infants on supplementation with varying doses of DHA has shown numerous benefits: reduction in incidence of bronchopulmonary dysplasia and hay fever, ${ }^{69}$ higher MDI scores at 18 months' corrected age, ${ }^{70}$ higher visual acuity, ${ }^{71}$ increased length and weight at 12 months' and 18 months' corrected age, ${ }^{72}$ better recognition memory, and higher problemsolving scores at 6 months. ${ }^{73}$

A recent meta-analysis by Moon et al. $^{74}$ reported no clear longterm benefits of LCPUFA on visual and cognitive development. However, the authors also stated that the studies included were quite heterogeneous in methodology and hence interpretation of combined data was difficult. A detailed discussion on DHA and ARA supplementation in preterm infants is outside the scope of this review. It must, however, be stressed that LCPUFA supplementation is not only necessary based on benefits seen in clinical studies, but also required to mirror the composition of human milk.

\subsubsection{Indian perspective on DHA and ARA supplementation}

Breast milk concentrations of DHA and ARA in Indian mothers of term and preterm infants were studied by Kilari et al. ${ }^{75,76}$ In a cohort of Indian mothers of term infants predominantly comprising vegetarians, the mean DHA and ARA concentrations were $0.2 \mathrm{~g} /$ $100 \mathrm{~g}$ and $1 \mathrm{~g} / 100 \mathrm{~g}$ of total fatty acids respectively. ${ }^{75}$ In a study of mothers of preterm infants, the mean breast milk DHA concentrations were higher $(0.3 \mathrm{~g} / 100 \mathrm{~g})$ compared to mothers of term infants, although there were no differences in ARA concentrations $(1 \mathrm{~g} / 100 \mathrm{~g}) .^{75,76}$ Experts believe that in the case of premature delivery, maternal-to-fetal transfer of DHA is low due to a shorter duration of pregnancy. Also, the volume of milk consumed by preterm infants is considerably less during the initial days after birth. The higher DHA concentrations in breast milk of mothers of preterm infants may be an adaptive mechanism to meet the high nutrient needs of preterm infants. ${ }^{76}$

Studies suggest that maternal DHA intake is dependent on the type of fat ingested. Huffman et al. reported in their literature review that DHA intake was lowest in Indian pregnant women in the third trimester compared to pregnant women from developing countries. ${ }^{26}$ The mean DHA and ARA intake in Indian pregnant women was $11 \mathrm{mg}$ and $33 \mathrm{mg}$ respectively in the third trimester. ${ }^{77}$ Interestingly, Bangladeshi women consumed $11 \%$ of fats in their diet during pregnancy, which accounted for a consumption of $30 \mathrm{mg}$ of DHA compared to Indian women, who consumed $25 \%$ of fats in their diet during pregnancy, accounting for only $11 \mathrm{mg}$ of DHA. ${ }^{26,77,78}$ The low DHA intake could be attributed to the poor intake of fish in Indian women. Furthermore, the intake of LA was considerably high due to consumption of sunflower and safflower oil, while the intake of ALA was low. High LA intake affects the conversion of ALA into EPA and DHA and thus may also contribute to the low maternal DHA status in Indian women. ${ }^{77}$ Another study in South Indian pregnant women demonstrated a low median intake of ALA, EPA, and DHA $(0.56,0.003$, and $0.011 \mathrm{~g} / \mathrm{day}$, respectively), but a high median intake of LA ( $14.6 \mathrm{~g} /$ day) during pregnancy. $^{79}$

Poor maternal fish intake during the third trimester in pregnant Indian women was significantly associated with an increased risk of low-birth-weight (LBW) infants, suggesting that n-3 supplementation during pregnancy may have a significant impact on birth outcomes. ${ }^{77}$ Despite its benefits, fish is also a source of several contaminants including mercury, polychlorinated biphenyls, dioxins etc. ${ }^{80}$ High maternal fish intake may lead to higher prenatal mercury exposure and has been linked to neurodevelopmental abnormalities in children. The benefits of maternal fish intake should be weighed against possible deleterious effects of mercury contamination from sea food. Recent literature review suggested that the benefits of moderate fish consumption during pregnancy outweighs any potential adverse effects and it is important to ensure that the type of fish consumed contains low mercury concentrations. ${ }^{81}$

There is paucity of data on benefits of DHA and ARA supplementation in infants in the Indian population. However, considering the beneficial effects of LCPUFA supplementation on various aspects of child development, the goal of supplementation is to be close to the composition of human milk.

\subsection{Phospholipids}

Phospholipids are indispensable components of all cellular and sub-cellular membranes. ${ }^{82}$ They are broadly classified into glycerophospholipids, the major structural lipids in eukaryotic membranes; and sphingolipids, another class of structural lipids. ${ }^{83}$ Phospholipids are involved in several vital functions, including immunity and inflammatory responses, neuronal signaling, and attenuation of the effects of age-related diseases. ${ }^{84}$ In addition, PLs act as carriers of DHA to the brain. ${ }^{8,9}$ Animal studies suggest that supplementation of phospholipids could restore the ideal composition of PUFAs in the brain cell membrane. ${ }^{10,11}$ Phospholipids have also demonstrated improvement in learning and memory deficits in rats by facilitating hippocampal synaptic transmission in the brain. ${ }^{85}$ Thus, oral supplementation of phospholipids may be essential during pregnancy and infancy, when DHA provision into the brain is essential for neurological development. ${ }^{7}$ Phospholipids correspond to $0.2 \%-2.0 \%$ of fats present in human milk. Their levels in the human milk ranged from $9.8-47.4 \mathrm{mg} 100 \mathrm{~g}^{-1}$, with the majority of the PLs being sphingomyelins (SM) and phosphatidylcholinse (PC). The high content of SM and PC is important, as the majority of the total choline content (17\%), essential for rapid organ growth and membrane biosynthesis, comes from these lipids. ${ }^{86}$

\section{DHA and ARA in infant formulas: recommendations}

The Food and Agricultural Organization (FAO) report on fats and fatty acids has recommended nutrient intake value of DHA and ARA in infants aged 0-24 months (Table 3). ${ }^{87}$ According to the FAO, there is convincing evidence that DHA plays a critical role in retinal and brain development. Also, based on probable evidence, FAO states that DHA should be considered conditionally essential during the first six months of life, due to its limited and highly variable synthesis from ALA. ${ }^{87}$

Based on a systematic review of the available scientific literature, a global expert group recommends a nutrient intake of $100 \mathrm{mg}$ DHA/day and $140 \mathrm{mg}$ ARA/day in term infants in the first 
Table 3

Recommended dietary intake of DHA and ARA in infants aged 0-24 months. ${ }^{87}$

\begin{tabular}{|c|c|c|c|}
\hline Fatty acid & Age group & Measure & Upper nutrient limits \\
\hline ARA & $\begin{array}{l}0-6 \text { mos } \\
6-12 \text { mos } \\
12-24 \text { mos } \\
0-6 \text { mos }\end{array}$ & $\begin{array}{l}\text { - } \mathrm{AI} \\
\text { - } \mathrm{AI} \\
\text { - } \mathrm{AI} \\
\text { - } \mathrm{AI}\end{array}$ & $\begin{array}{l}-0.20 \%-0.36 \% \mathrm{FA} \\
\text { - } 10-12 \mathrm{mg} / \mathrm{kg} \\
\text { - } 10-12 \mathrm{mg} / \mathrm{kg} \\
\text { - } 0.4 \%-0.6 \% \mathrm{FA}\end{array}$ \\
\hline
\end{tabular}

DHA: Docosahexaenoic acid; ARA: Arachidonic acid; AI: Adequate intake; FA: Fatty acid.

six months of life, and that the infant formulas should provide at least $0.3 \%$ of fatty acids as DHA along with ARA. The panel also recommends a continued supply of $100 \mathrm{mg}$ DHA/day during the second 6 months, with no quantitative advice on ARA intake, due to the lack of sufficient data and due to considerable variation in the amount of ARA provided by complementary foods across different countries. ${ }^{66}$ Also, complementary foods available in developing countries are mostly cereal-based and have a low LCPUFA concentration. ${ }^{1}$

The Dietary Guidelines for Americans (DGA) 2010 recommend consuming 8-12 ounces of seafood per week in pregnant and lactating women, from a variety of seafood types. Intake of 8 ounces of seafood is equivalent to approximately $250 \mathrm{mg}$ of DHA and EPA. ${ }^{88}$

Based on the average concentrations of DHA and ARA in human milk, several international expert groups have published recommendations on DHA and ARA levels in infant formulas. According to these recommendations, the average DHA levels range from $0.2 \%$ to $0.4 \%$ of fatty acids and the ARA levels range from $0.35 \%$ to $0.7 \%$ of fatty acids. ${ }^{89-91}$ Infant formulas typically provide $140 \mathrm{mg} /$ day of ARA and $100 \mathrm{mg} /$ day of DHA, with an estimated milk intake of 750 to $800 \mathrm{~mL} /$ day. $^{34}$ This corresponds to a DHA:ARA ratio ranging from $1: 1$ to $1: 2 .^{89-91}$ Recently, the Food Safety and Standards Authority of India (FSSAI) made amendments to the Food Safety and Standards Regulations, 2011, which included amendments pertaining to the use of ARA and DHA in infant formulas. According to the recent notification by the FSSAI, algal and fungal oil can be used as sources of DHA and ARA from Crypthecodinium cohnii, Mortierella alpina, Schizochytrium sp., and Ulkenia sp. at the level of maximum 0.5 per cent. Docosahexaenoic acid of total fatty acids and the DHA:ARA ratio must be a minimum of $1: 1$; and if a claim related to DHA is made, the DHA content should not be less than $0.2 \%$ of total fatty acids. ${ }^{92}$

\section{Importance of DHA:ARA ratio}

The mean concentrations of DHA and ARA in breast milk can vary based on the maternal diet. Brenna et al. suggest that the DHA: ARA ratio of human milk is around $1: 1.5$, based on the mean concentrations of these LCPUFAs worldwide. ${ }^{34} \mathrm{~A}$ proper balance between DHA and ARA is essential for optimal cognitive development. This was demonstrated in two randomized controlled trials of term infants, in which different levels of DHA (0.32\%, 0.64\%, and 0.96\%) supplementation, along with an ARA level of $0.64 \%$, were used. The two lower doses of DHA were associated with positive outcomes in terms of increased attention, better Weschler Primary Preschool Scales of Intelligence scores, and better vocabulary compared with the unsupplemented group. However, cognitive performance was found to be attenuated in infants administered the highest dose $(0.96 \%)$ of DHA with $0.64 \%$ ARA. ${ }^{61,93}$ A study was conducted in 12-week-old rat baboons randomized to the control, moderate LCPUFA (DHA: 0.33\%, ARA: $0.67 \%$ ), and high LCPUFA (DHA: $1.0 \%$, ARA: $0.67 \%$ ) groups. The group with highest levels of DHA showed decreased ARA levels in two brain areas, suggesting competition of DHA with ARA. ${ }^{94}$ This suggests that high doses of DHA may suppress the benefits of ARA. Furthermore, studies suggest that DHA supplementation in infant formulas without ARA results in a reduction of plasma ARA by up to $40 \% .{ }^{95,96}$

So, there has been some deliberations on the most appropriate DHA:ARA ratio in infant formulas. For supplementation in infant formulas, recommendations are that DHA:ARA can range from 1:1 to $1: 2$.

\section{Conclusion and future perspectives}

There is a rapid accumulation of DHA and ARA in the infant's brain in the early years of life, highlighting the significance of DHA and ARA in brain development. During this time, infants receive DHA and ARA either through breast milk or through infant formulas supplemented with DHA and ARA, and later through complementary foods. The levels of DHA in breast milk vary significantly and depend on the maternal diet and maternal DHA status. Optimizing maternal nutrition to include sufficient LCPUFA intake to improve infant LCPUFA status is considered ideal. However, in a country such as India, where vegetarian diets are commonly followed, the availability of preformed LCPUFA is practically very low. Furthermore, DHA intake is the lowest in India compared to other developing countries, highlighting the need for DHA supplementation during pregnancy and lactation. Supplementation of DHA during pregnancy and lactation is associated with improved visual and cognitive development in the infant. Alternatively, in situations where infants cannot be breast fed, DHA-supplemented infant formulas and DHA-rich foods can help in optimizing infants' DHA status. Even though there is heterogeneity of results from clinical studies, there is reasonable clinical evidence supporting the visual, cognitive, and other health benefits of DHA and ARA in infants. Current recommendations from international expert groups suggest DHA levels of $0.2 \%$ to $0.4 \%$ of fatty acids and ARA levels of $0.35 \%$ and $0.7 \%$ of fatty acids are appropriate. Mimicking human milk composition is becoming the recommended approach for attaining optimal neurocognitive benefits.

\section{Conflict of interest}

The authors have none to declare.

\section{Acknowledgements}

We would like to thank BioQuest Solutions for their editorial services. The support for this manuscript is from Nestle Nutrition Institute, South Asia.

\section{References}

1. Hadley KB, Ryan AS, Forsyth S, Gautier S, Salem N. The essentiality of arachidonic acid in infant development. Nutrients. 2016;8:216. 
2. Benton D. The influence of dietary status on the cognitive performance of children. Mol Nutr Food Res. 2010;54:457-470.

3. Nyaradi A, Li J, Hickling S, Foster J, Oddy WH. The role of nutrition in children's neurocognitive development, from pregnancy through childhood. Front Hum Neurosci. 2013;7:97.

4. Choe MS, Ortiz-Mantilla S, Makris N, et al. Regional infant brain development: An MRI-based morphometric analysis in 3 to 13 month olds. Cereb Cortex. 2013;23:2100-2117.

5. Gale CR, O'Callaghan FJ, Bredow M, Martyn CN, Avon Longitudinal Study of Parents and Children Study Team. The influence of head growth in fetal life, infancy, and childhood on intelligence at the ages of 4 and 8 years. Pediatrics. 2006;118:1486-1492.

6. Yehuda S, Rabinovitz S, Mostofsky DI. Essential fatty acids are mediators of brain biochemistry and cognitive functions. J Neurosci Res. 1999;56:565-570.

7. Küllenberg D, Taylor LA, Schneider M, Massing U. Health effects of dietary phospholipids. Lipids Health Dis. 2012;11:3.

8. Thies F, Pillon C, Moliere P, Lagarde M, Lecerf J. Preferential incorporation of sn2 lysoPC DHA over unesterified DHA in the young rat brain. Am J Physiol. 1994;267(5 Pt 2):R1273-79.

9. Lagarde M, Bernoud N, Brossard N, et al. Lysophosphatidylcholine as preferred carrier form of docosahexaenoic acid to the brain. $J$ Mol Neurosci. 2001;16(2-3)201-204 discussion 215-21.

10. Favreliere S, Perault MC, Huguet F, et al. DHA-enriched phospholipid diets modulate age-related alterations in rat hippocampus. Neurobiol Aging. 2003;24:233-243.

11. Carrie I, Smirnova M, Clement M, De Javel D, Francès H, Bourre JM Docosahexaenoic acid-rich phospholipid supplementation: effect on behavior, learning ability, and retinal function in control and $n-3$ polyunsaturated fatty acid deficient old mice. Nutr Neurosci. 2002;5:43-52.

12. Innis S. Dietary omega 3 fatty acids and the developing brain. Brain Res. 2008;1237:35-43.

13. Morse NL. Benefits of docosahexaenoic acid, folic acid, vitamin D and iodine on foetal and infant brain development and function following maternal supplementation during pregnancy and lactation. Nutrients. 2012;4:799-840.

14. Weiser MJ, Butt CM, Mohajeri MH. Docosahexaenoic acid and cognition throughout the lifespan. Nutrients. 2016;8:99.

15. Topuz OK. Algal oil: a novel source of omega-3 fatty acids for human nutrition. Sci Bull Ser F. Biotechnol. 2016;XX:178-183.

16. Bradbury J. Docosahexaenoic acid (DHA): an ancient nutrient for the modern human brain. Nutrients. 2011;3:529-554.

17. Pender-Cudlip MC, Krag KJ, Martini D, et al. Delta-6-desaturase activity and arachidonic acid synthesis are increased in human breast cancer tissue. Cancer Sci. 2013:104:760-764.

18. Heaton AE, Meldrum SJ, Foster JK, Prescott SL, Simmer K. Does docosahexaenoic acid supplementation in term infants enhance neurocognitive functioning in infancy? Front Hum Neurosci. 2013:7:774.

19. Tosi F, Sartori F, Guarini P, Olivieri O, Martinelli N. Delta-5 and delta-6 desaturases: crucial enzymes in polyunsaturated fatty acid-related pathways with pleiotropic influences in health and disease. Adv Exp Med Biol. 2014:824:61-81.

20. Calder PC. Omega-3 polyunsaturated fatty acids and inflammatory processes: nutrition or pharmacology? Br J Clin Pharmacol. 2013;75:645-662.

21. Koletzko B, Lattka E, Zeilinger S, et al. Genetic variants of the fatty acid desaturase gene cluster predict amounts of red blood cell docosahexaenoic and other polyunsaturated fatty acids in pregnant women: findings from the Avon Longitudinal Study of Parents and Children. Am J Clin Nutr. 2011;93 (1):211-219.

22. Abedi E, Sahari MA. Long-chain polyunsaturated fatty acid sources and evaluation of their nutritional and functional properties. Food Sci Nutr. 2014:2:443-463.

23. Burdge GC, Jones AE, Wootton SA. Eicosapentaenoic and docosapentaenoic acids are the principal products of alpha-linolenic acid metabolism in young men. Br J Nutr. 2002;88:355-363.

24. Burdge GC, Wootton SA. Conversion of alpha-linolenic acid to eicosapentaenoic, docosapentaenoic and docosahexaenoic acids in young women. Br J Nutr. 2002;88:411-420.

25. Sanders TA. DHA status of vegetarians. Prostaglandins Leukot Essent Fatty Acids. 2009;81:137-141.

26. Huffman SL, Harika RK, Eilander A, Osendarp SJ. Essential fats: how do they affect growth and development of infants and young children in developing countries? a literature review. Matern Child Nutr. 2011;7(Suppl. 3):44-65.

27. Salem Jr. NJr., Wegher B, Mena P, Uauy R. Arachidonic and docosahexaenoic acids are biosynthesized from their 18-carbon precursors in human infants. Proc Natl Acad Sci U S A. 1996:93:49-54.

28. Kabaran S, Besler HT. Do fatty acids affect fetal programming? J Health Popul Nutr. 2015;33:14

29. Martinez M. Tissue levels of polyunsaturated fatty acids during early human development. J Pediatr. 1992;120(4 Pt 2):S129-138.

30. Lauritzen L, Hansen HS, Jørgensen MH, Michaelsen KF. The essentiality of long chain n-3 fatty acids in relation to development and function of the brain and retina. Prog Lipid Res. 2001;40:1-94.

31. Valentine CJ. Maternal dietary DHA supplementation to improve inflammatory outcomes in the preterm infant. Adv Nutr. 2012;3:370-376.

32. Kuipers RS, Luxwolda MF, Offringa PJ, Boersma ER, Dijck-Brouwer DA, Muskie FA. Fetal intrauterine whole body linoleic, arachidonic, and docosahexaenoic acid contents and accretion rates. Prostaglandins Leukot Essent Fat Acids. $2011 ; 86: 13-20$

33. Niers L, Stasse-Wolthuis M, Rombouts FM, Rijkers GT. Nutritional support for the infant's immune system. Nutr Rev. 2007;65:347-360.

34. Brenna JT, Varamini B, Jensen RG, Diersen-Schade DA, Boettcher JA, Arterburn LM. Docosahexaenoic and arachidonic acid concentrations in human breast milk worldwide. Am J Clin Nutr. 2007;85:1457-1464.

35. Carlson SE. Docosahexaenoic acid supplementation in pregnancy and lactation. Am J Clin Nut. 2009;89:678S-684S.

36. Ruan C, Liu X, Man H, et al. Milk composition in women from five different regions of China: the great diversity of milk fatty acids. J Nutr. 1995;125:29932998.

37. Glew RH, Wold RS, Corl B, Calvin CD, Vanderjagt DJ. Low docosahexaenoic acid in the diet and milk of American Indian women in New Mexico. J Am Diet Assoc. 2011:111:744-748.

38. World Health Organization (WHO). Global Strategy on Infant and Young Child Feeding. Available from: http://www.who.int/nutrition/topics/ infantfeeding_recommendation/en/ Accessed on 20 January 2017.

39. World Health Organization (WHO). Nutrient Adequacy of Exclusive Breastfeeding for the Term Infant during the First Six Months of Life. Available from: http://www.who.int/nutrition/publications/infantfeeding/9241562110/ en/ Accessed on 20 January 2017.

40. Dunstan JA, Mori TA, Barden A, et al. Effects of n-3 polyunsaturated fatty acid supplementation in pregnancy on maternal and foetal erythrocyte fatty acid composition. Eur J Clin Nutr. 2004;58:429-437.

41. Gibson RA, Neumann MA, Makrides M. Effect of increasing breast milk docosahexaenoic acid on plasma and erythrocyte phospholipid fatty acids and neural indices of exclusively breast fed infants. Eur J Clin Nutr. 1997;51:578584.

42. Helland IB, Saugstad OD, Saarem K, Van Houwelingen AC, Nylander G, Drevon CA. Supplementation of $n-3$ fatty acids during pregnancy and lactation reduces maternal plasma lipid levels and provides DHA to the infants. J Matern Fetal Neonatal Med. 2006;19:397-406.

43. Dunstam J, Simmer K, Dixon J, Saugstad OD, Drevon CA. Cognitive assessment of children at age 2.5 years after maternal fish oil supplementation in pregnancy: a randomised controlled trial. Arch Dis Child Fetal Neonatal Ed. 2008;93:F45-F50.

44. Judge MP, Harel O, Lammi-Keefe CJ. A docosahexaenoic acid-functional food during pregnancy benefits infant visual acuity at four but not six months of age. Lipids. 2007;42:117-122

45. Jacques C, Levy E, Muckle E, et al. Long-term effects of prenatal omega-3 fatty acid intake on visual function in school-age children. J Pediatr. 2011;158:73-80 e1.

46. Jacobson JL, Jacobson SW, Muckle G, Kaplan-Estrin M, Ayotte P, Dewailly E. Beneficial effects of a polyunsaturated fatty acid on infant development: evidence from the inuit of arctic Quebec. J Pediatr. 2008;152:356-364.

47. Kannass KN, Colombo J, Carlson SE. Maternal DHA levels and toddler free-play attention. Dev Neuropsychol. 2009;34:159-174.

48. Judge MP, Harel O, Lammi-Keefe CJ. Maternal consumption of docosahexaenoic acid-ontaining functional food during pregnancy: benefit for infant performance on problem-solving but not on recognition memory tasks at age 9 mo. Am J Clin Nutr. 2007;85:1572-1577.

49. Helland IB, Smith L, Saarem K, Saugstad OD, Drevon CA. Maternal supplementation with very-long-chain n-3 fatty acids during pregnancy and lactation augments children's IQ at 4 years of age. Pediatrics. 2003;111: e39-e44.

50. Florey CD, Leech AM, Blackhall A. Infant feeding and mental and motor development at 18 months of age in first born singletons. Int J Epidemiol. 1995;24:S21-26.

51. Temboury MC, Otero A, Polanco I, Arribas E. Influence of breast-feeding on the infant's intellectual development. J Pediatr Gastroenterol Nutr. 1994;18:32-36.

52. Anderson JW, Johnson BM, Remley DT. Breast feeding and cognitive development: a meta-analysis. Am J Clin Nutr. 1999;70:525-535.

53. Birch EE, Garfield S, Hoffman DR, Uauy R, Birch DG. A randomized controlled trial of early dietary supply of long-chain polyunsaturated fatty acids and mental development in term infants. Dev Med Child Neurol. 2000;42:174-181.

54. Pastor N, Soler B, Mitmesser SH, Ferguson P, Lifschitz C. Infants fed docosahexaenoic acid- and arachidonic acid-supplemented formula have decreased incidence of bronchiolitis/bronchitis the first year of life. Clin Pediatr (Phila). 2006;45:850-855.

55. Birch EE, Carlson SE, Hoffman DR, et al. The DIAMOND (DHA Intake and Measurement Of Neural Development) study: a double-masked, randomized controlled clinical trial of the maturation of infant visual acuity as a function of the dietary level of docosahexaenoic acid. Am J Clin Nutr. 2010:91:848-859.

56. Drover JR, Hoffman DR, Castañeda YS, et al. Cognitive function in 18-monthold term infants of the DIAMOND study: a randomized, controlled clinical trial with multiple dietary levels of docosahexaenoic acid. Early Hum Dev. 2011;87:223-230.

57. Meldrum SJ, D'Vaz N, Simmer K, Dunstan JA, Hird K, Prescott SL. Effects of highdose fish oil supplementation during early infancy on neurodevelopment and language: a randomised controlled trial. Br J Nutr. 2012;108:1443-1454.

58. D'Vaz N, Meldrum SJ, Dunstan JA, et al. Fish oil supplementation in early infancy modulates developing infant immune responses. Clin Exp Allergy. 2012:42:1206-1216. 
59. Lapillonne A, Pastor N, Zhuang W, Scalabrin D. Infants fed formula with added long chain polyunsaturated fatty acids have reduced incidence of respiratory illnesses and diarrhea during the first year of life. BMC Pediatr. 2014;14:168

60. Foiles AM, Kerling EH, Wick JA, Scalabrin DM, Colombo J, Carlson SE. Formula with long-chain polyunsaturated fatty acids reduces incidence of allergy in early childhood. Pediatr Allergy Immunol. 2016;27:156-161.

61. Colombo J, Carlson SE, Cheatham CL, et al. Long-term effects of LCPUFA supplementation on childhood cognitive outcomes. Am J Clin Nutr. 2013;98:403-412.

62. Willatts P, Forsyth S, Agostoni C, Casaer P, Riva E, Boehm G. Effects of longchain PUFA supplementation in infant formula on cognitive function in later childhood. Am J Clin Nutr. 2013;98:536S-542.

63. Qawasmi A, Landeros-Weisenberger A, Leckman JF, Bloch MH. Meta-analysis of long-chain polyunsaturated fatty acid supplementation of formula and infant cognition. Pediatrics. 2012;129:1141-1149.

64. Simmer K, Patole SK, Rao SC. Long-chain polyunsaturated fatty acid supplementation in infants born at term. Cochrane Database Syst Rev. 2011; (12):CD000376.

65. Qawasmi A, Landeros-Weisenberger A, Bloch MH. Meta-analysis of LCPUFA supplementation of infant formula and visual acuity. Pediatrics. 2013;131: e262-e272.

66. Koletzko B, Boey CCM, Campoy C, et al. Current information and Asian perspectives on long-chain polyunsaturated fatty acids in pregnancy, lactation, and infancy: systematic review and practice recommendations from an early nutrition academy workshop. Ann Nutr Metab. 2014;65:49-80.

67. Jasani B, Simmer K, Patole SK, Rao C. Long chain polyunsaturated fatty acid supplementation in infants born at term. Cochrane Database Syst Rev. 2017;(3) CD000376.

68. Berenhauser AC, Pinheiro do Prado AC, da Silva RC, Gioielli LA. Fatty acid composition in preterm and term breast milk. Int J Food Sci Nutr. 2012;63:318325.

69. Manley BJ, Makrides M, Collins CT, et al. High-dose docosahexaenoic acid supplementation of preterm infants: respiratory and allergy outcomes. Pediatrics. 2011;128:e71-e77.

70. Makrides M, Gibson RA, McPhee AJ, et al. Neurodevelopmental outcomes of preterm infants fed high-dose docosahexaenoic acid: a randomized controlled trial. JAMA. 2009;301:175-182.

71. Smithers LG, Gibson RA, McPhee A, Makrides M. Higher dose of docosahexaenoic acid in the neonatal period improves visual acuity of preterm infants: results of a randomized controlled trial. Am J Clin Nutr. 2008;88:1049-1056.

72. Collins CT, Makrides M, Gibson RA, et al. Pre- and post-term growth in preterm infants supplemented with higher-dose DHA: a randomised controlled trial. Br J Nutr. 2011;105:1635-1643.

73. Henriksen C, Haugholt K, Lindgren M, et al. Improved cognitive development among preterm infants attributable to early supplementation of human milk with docosahexaenoic acid and arachidonic acid. Pediatrics. 2008;121:11371145 .

74. Moon K, Rao SC, Schulzke SM, Patole SK, Simmer K. Long chain polyunsaturated fatty acid supplementation in preterm infants. Cochrane Database Sys Rev. 2016;(12) CD000375.

75. Kilari AS, Mehendale SS, Dangat KD, et al. Long chain polyunsaturated fatty acids in mothers and term babies. J Perinat Med. 2009:37:513-518.

76. Kilari AS, Mehendale SS, Dangat KD, et al. Long chain polyunsaturated fatty acids in mothers of preterm babies. J Perinat Med. 2010;38:659-664.
77. Muthayya S, Dwarkanath P, Thomas T, et al. The effect of fish and omega-3 LCPUFA intake on low birth weight in Indian pregnant women. Eur J Clin Nutr. 2009;63:340-346.

78. Yakes EA. Polyunsaturated Fatty Acid Intake and Status of Breast Fed and NonBreast Fed Bangladeshi Children 24-47 Months of Age. Davis: University of California; $2010 \mathrm{PhD}$, Dissertation.

79. Dwarkanath P, Muthayya S, Thomas T, et al. Polyunsaturated fatty acid consumption and concentration among South Indian women during pregnancy. Asia Pac J Clin Nutr. 2009;18:389-394.

80. Oken E, Radesky JS, Wright RO, et al. Maternal fish intake during pregnancy, blood mercury levels, and child cognition at age 3 years in a US cohort. Am J Epidemiol. 2008;167(10):1171-1181.

81. Starling P, Charlton K, McMahon AT, et al. Fish intake during pregnancy and foetal neurodevelopment-a systematic review of the evidence. Nutrients. 2015; 7:2001-2014.

82. Li J, Wang X, Zhang T, et al. A review on phospholipids and their main applications in drug delivery systems. Asian J Pharm Sci. 2015;10:81-98.

83. van Meer G, Voelker DR, Feigenson GW. Membrane lipids: where they are and how they behave. Nat Rev Mol Cell Biol. 2008;9:112-124.

84. Giuffrida F, Cruz-Hernandez C, Flück B, et al. Quantification of phospholipids classes in human milk. Lipids. 2013;48:1051-1058.

85. Yaguchi T, Nagata T, Nishizaki T. Dilinoleoylphosphatidylcholine ameliorates scopolamine-induced impairment of spatial learning and memory by targeting alpha7 nicotinic ACh receptors. Life Sci. 2009;84:263-266.

86. Cilla A, Diego Quintaes K, Barberá R, Alegria A. Phospholipids in human milk and infant formulas: benefits and needs for correct infant nutrition. Crit Rev Food Sci Nutr. 2016;56:1880-1892.

87. Food and Agricultural Organization. Fats and Fatty Acids in Human Nutrition Report of an Expert Consultation. November 2008, Geneva.

88. US Department of Agriculture. Maternal Intake of Seafood Omega-3 Fatty Acids and Infant Health: A Review of the Evidence. Available at https://www.cnpp. usda.gov/sites/default/files/nutrition_insights_uploads/Insight46.pdf Accessed on 2 Mar 2017.

89. The British Nutrition Foundation. Unsaturated fatty acids: Nutritional and Physiological Significance. London: Chapman \& Hall; 1992:152-163.

90. Food and Agricultural Organization of the United Nations/World Health Organization Joint Expert Consultation. Lipids in early development. Fats and Oils in Human Nutrition, 57FAO Food and Nutri Pap; 1994:49-55.

91. Simopoulos AP, Leaf A, Salem Jr. NJr.. Workshop on the essentiality of and recommended dietary intakes for omega-6 and omega-3 fatty acids. J Am Coll Nutr. 1999;18:487-489.

92. Food Safety and Standards Authority of India Notification. 13th July.

93. Colombo J, Carlson SE, Cheatham CL, Fitzgerald-Gustafson KM, Kepler A, Doty T. Long-chain polyunsaturated fatty acid supplementation in infancy reduces heart rate and positively affects distribution of attention. Pediatr Res. 2011;70:406-410.

94. Hsieh AT, Anthony JC, Diersen-Schade DA, et al. The influence of moderate and high dietary long chain polyunsaturated fatty acids (LCPUFA) on baboon neonate tissue fatty acids. Pediatr Res. 2007;61:537-545.

95. Makrides M, Neumann MA, Jeffrey B, Lien EL, Gibson RA. A randomized trial of different ratios of linoleic to alpha-linolenic acid in the diet of term infants: effect on visual function and growth. Am J Clin Nutr. 2000;71:120-129.

96. Uauy R, Treen M, Hoffman DR. Essential fatty acid metabolism and requirements during development. Semin Perinatol. 1989;13:118-130. 